\title{
Multi-method Approach in Fulfilling Clean Water Resources for Inhabitants in A Rural Area: Preliminary Results
}

\author{
Aditya Pratama ${ }^{1, *}$, Abdullah Husna ${ }^{2}$, Ryan Dwi Wahyu Ardi ${ }^{3,4}$, Yogi Adi Prasetya 5 \\ ${ }^{1}$ Research Center for Geotechnology, National Research and Innovation Agency (BRIN), JL. Sangkuriang, \\ Kompleks LIPI, Dago, Coblong, Bandung City, West Java 40135, Indonesia. \\ ${ }^{2}$ Research Center for Water Resources, Ministry of Public Work and Housing, Juanda 193, Bandung, 40135, \\ Indonesia. \\ ${ }^{3}$ Geological Engineering Study Program, Faculty of Earth Sciences and Technology, Institut Teknologi \\ Bandung, Jl. Ganesha No. 10, Lebak Siliwangi, Coblong, Bandung City, West Java 40132, Indonesia. \\ ${ }^{4}$ Agrotechnology Study Program, Faculty of Science and Technology, Universitas Nahdlatul Ulama \\ Purwokerto, Jl. Sultan Agung No. 42, Karangklesem, Purwokerto Selatan, Banyumas Regency, Central Java \\ 53144, Indonesia. \\ ${ }^{5}$ Petrology, Volcanology and Geothermal Group, Volkanologi, dan Geothermal. Geological Engineering, \\ Sumatran Institute of Technology, J1. Terusan Ryacudu, Way Huwi, Jati Agung, South Lampung, Lampung \\ 35365, Indonesia. \\ * Corresponding author: aditya.pratama@brin.go.id \\ Received: Nov 22, 2021; Accepted: Dec 18, 2021. \\ DOI: https://doi.org/10.31764/jpl.v2i2.6148
}

\begin{abstract}
Clean water scarcity is among the crucial issues for inhabitants at Cikakaban Village, Tasikmalaya City. The complexity of the geological and hydrogeological conditions around Cikakaban Village makes groundwater exploration quite difficult. Regionally, Cikakaban Village has low aquifer productivity and is located at the contact of two formations which are passed by a fault. Therefore, a multi-method approach should be used in water sources exploration to obtain comprehensive results. In this paper, we presented the preliminary results which consist of the detailed geological and hydrogeological conditions of Cikakaban Village and its surroundings based on direct field observations. These observations aim to know the lithology that composes the research area and its characteristics, the potential of aquifers and water resources around the research area, as well as an overview of the distribution of groundwater depth and its flow direction. Geological survey includes observation of outcrops, both lithological description and geological structure evidence. Meanwhile, hydrogeological survey includes observation wells (location plotting, measuring ground water level elevation and depth, and checking water quality), as well as observation of the other potential water resources around Cikakaban Village. It can be inferred that rocks underlying the study area have fine grain sizes, dominated by claystone and tuff. However, the presence of geological structure causes these rocks to potentially become productive aquifers. Other potential water sources around the research area are springs and intermittent rivers.
\end{abstract}

Keywords: Cikakaban Village, clean water resource, geology, hydrogeology, multi-method approach

\section{Introduction}

Clean water is a primary need in supporting people's daily lives. Not only for personal sanitation but also for household needs including for drinking. The fulfillment of clean water has become one of the Sustainable Development Goals (SDGs) (Rudiyanto, 2020 and Iskandar, 2021), which indicates how important clean water is for every single creature in the world.

Although this issue has become part of the SDGs, in fact, clean water crisis is still occurring. In the last five years, the average number of households in Indonesia that can access the clean water easily in urban and rural areas are only $86.07 \%$ and $68.76 \%$ respectively (Kemendes, 2020). This data shows that people in rural areas have limited access to the clean water, including the people of Cikakaban Village (Nugraha, 2016). 
Cikakaban Village is located in the south of Tamansari District, Tasikmalaya City, West Java (Figure 1). According to Riyadi and Wibowo (2007), Tamansari is the driest area in the city which has very low groundwater potential (only $819.49 \mathrm{~m}^{3} /$ day). This condition is aggravated by the its complex geological conditions, which is located at the boundary between Bentang Formation and young volcanic products (Figure 2). The contact between these two formations, which is passed by a fault, causes the complexity of rock permeability, affecting the migration of groundwater and its storage pattern (Agosta et al. 2010, 2012; Faulkner et al. 2010; and Bauer et al., 2016). As a result, groundwater exploration must be carried out through a multi-method approach to obtain comprehensive results, as suggested by Chowdary et al. (2008) and Lange et al. (2007). They integrated geophysical method with remote sensing and Geographical Information System (GIS). The data obtained were used to complement and confirm each other, thus the results are more accurate.

Overall, the methods used in this research are not only limited to geophysics, remote sensing, and GIS, but also geological, hydrogeological, and geochemical methods. However, in this paper, we only elaborate the preliminary results which is the geological and hydrogeological surveys. This stage aims to know the lithology that composes the research area and its characteristics, the potential of aquifers and water resources around the research area, as well as an overview of the distribution of groundwater depth and its flow direction. The information obtained at this stage is expected to assist not only the planning of measurement stage using geophysical method and water sampling, but also the interpretation of the results.

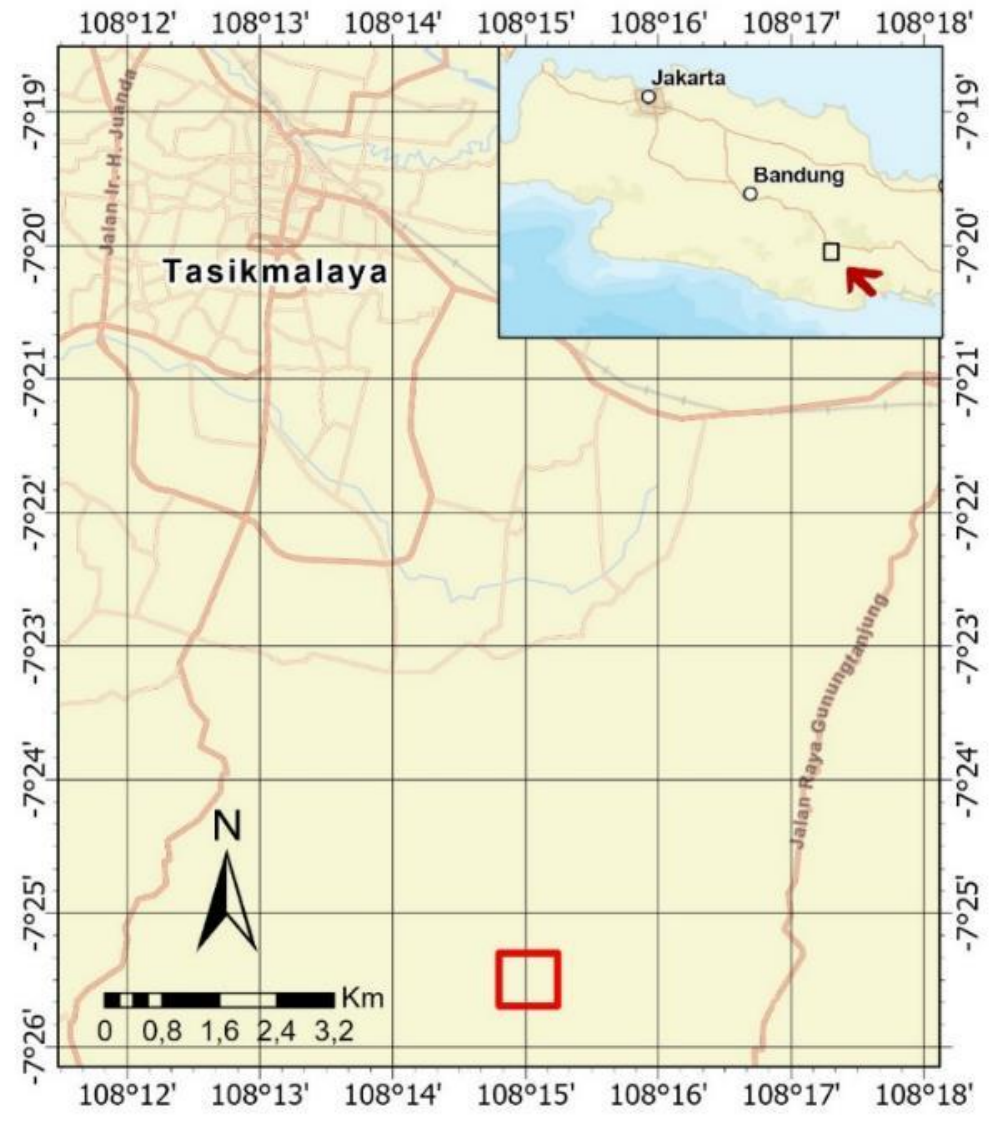

Fig 1. Map showing the study area (red box).

\section{Methods}

At this stage, geological and hydrogeological surveys were carried out to confirm and complete the data on the geological and hydrogeological maps. Because of the small research area, these surveys also covered the surrounding area in order to obtain sufficient data for further analysis. 
Before conducting the surveys, we analyzed satellite image data Digital Elevation Model (DEM) obtained from www.tanahair.indonesia.go.id, the Geological Map of the Tasikmalaya Quadrangle, West Java (Budhitrisna, 1986) and the Hydrogeological Map of Indonesia (Soetrisno, 1983). The DEM data were converted into a contour map using the Quantum GIS (QGIS) software (open-source software). Based on these data, we conducted morphological observation to describe the geological conditions (especially related to lineament which indicates the presence of geological structure) and hydrogeological conditions (determination of recharge area and the presence of potential water resources). These descriptions were further confirmed and completed through field activities.

In geological survey, the observation of outcrops are conducted on both lithological description and geological structure evidence. The rock characteristics observed were textures (i.e. grain size, grain shape, fabric, sorting, and permeability), structures (i.e. layer boundary, fault, fold, and joint), and rock components/mineralogy. The observation of rock permeability was performed by rock drop test. In this test, small amount of water was dropped on the rock and observed by confirming whether the water seeps well, moderately or not at all. Meanwhile, the observations of the other characteristics were carried out macroscopically.

In hydrogeological survey, we conducted observation wells around the research area (location plotting, measuring groundwater level elevation and depth, and checking water quality), as well as observation of other water resources, such as rivers and springs. Measurement of the groundwater depth was carried out using the HMA geotechnical water level meter. Meanwhile, observation of rivers and springs was focused on knowing the location, the quality and quantity of water resources. Water quality observation was carried out on smell and color of water. Meanwhile, water quantity of rivers and springs was represented by volume water and water discharge respectively.

The data from observation wells were analyzed using spatial analysis. The MAT elevation/depth data was displayed on a MAT contour map using QGIS software (Figure 4). Because the groundwater level is estimated as free aquifer system with the topography as the main control over the flow direction, thus groundwater level mapping was created through the raster calculator method on topography. The direction of groundwater flow was made perpendicular to the contour of the groundwater level, based on Freeze and Chery (1979).

\section{Results and Discussion}

\subsection{Geological Setting of Research Area}

Based on the Geological Map of the Tasikmalaya Quadrangle, West Java by Budhitrisna (1986), the research area is located at the boundary between the Quaternary Young Volcanic Rock Formation (Qvg) and the Tertiary Bentang Formation (Tmpb) (Figure 2). In addition, the study area is also located right on the fault line (estimated), which is interpreted as a right-lateral fault (Budhitrisna, 1986).

In addition, Figure 2 shows that the study area and its surroundings have quite complex geological conditions. They are formed by at least three rock formation with various lithologies, including volcanic products, clastic sediments, and non-clastic sediments. There are four faults that intersect some of the rock formations mentioned above.

Here the observation of rock outcrops has been carried out in 20 locations scattered around the study area (Figure 2). The coordinates of all locations can be seen in Table 1. In general, the location of outcrop observation can be divided into two parts, in the north part of the study area (CK7-CK14) and in the south part of the study area (CK2-CK6 and CK15-CK23) (Figure 2). The dominant lithology in the northern part has coarse grain size and good permeability, where the lithology consists of sandstone, volcanic breccia, clastic limestone, and lapilli (Supplementary Material Figures S7-S16). Meanwhile, the dominant lithology in the southern part has fine grain sizes with moderate to poor permeability (Supplementary Material Figures S1-S6 and S17-S24). The lithologies are consist of tuff, claystone, and basaltic lava. The detailed hand specimens descriptions are explained in the Supplementary Materials. 

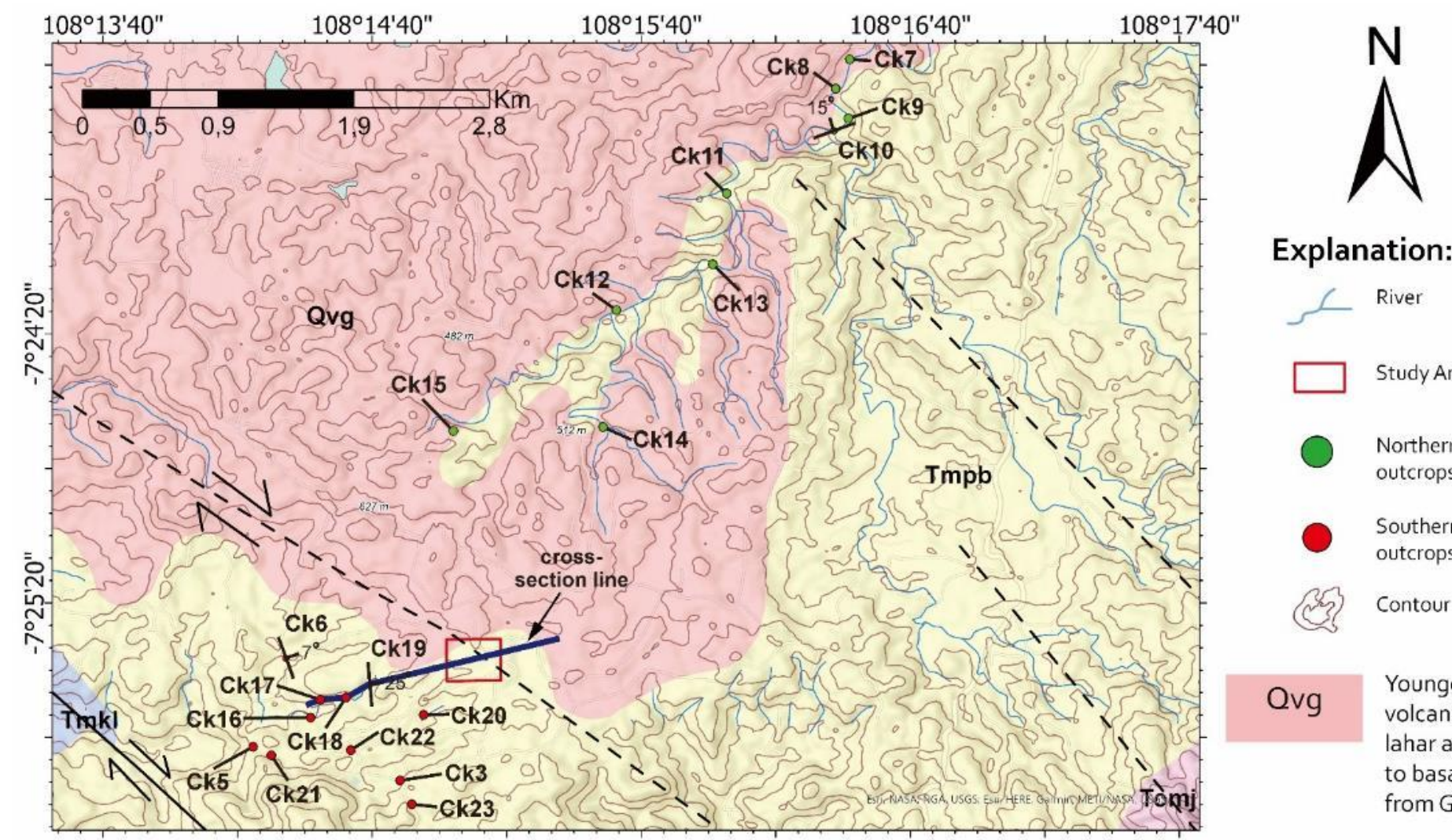

Explanation:

Tmpb Bentang Formation: Tuffaceous sandstone, sandstine, calcareous sandstone, conglomerate, volcanic breccia, tuff, tuffaceous clastone, tuff breccia, calcareous breccia, limestone, claystone, lignit intercalations. Thickness about $750 \mathrm{~m}$.

Tmkl Kalipucang Limestone: Coral limestone, massive and cavernous, locally bedded. Thickness about $150 \mathrm{~m}$

Tomj Jampang Formation: Andesitic to basaltic volcanic breccia, lava and tuff, tuffaceous sandstone, with intercalation of sandstone, siltstone, claystone and limestone. Thickness more than $1000 \mathrm{~m}$

Fig 3. Geological map of study area and its surroundings (modified from Budhitrisna (1986). 
Table 1. The outcrop locations (coordinate in UTM with 48S zone).

\begin{tabular}{cccc}
\hline Outcrops & Longitude & Lattitude & Elevation (mdpl) \\
\hline CK2 and CK6 & 195226 & 9178245 & 373 \\
CK3 & 196013 & 9177411 & 428 \\
CK4 and CK5 & 195007 & 9177638 & 365 \\
CK7 & 199054 & 9182377 & 337 \\
CK8 & 198965 & 9182173 & 332 \\
CK9 & 199059 & 9181972 & 331 \\
CK10 & 198954 & 9181886 & 335 \\
CK11 & 198223 & 9181452 & 361 \\
CK12 & 197473 & 9180647 & 368 \\
CK13 & 198131 & 9180965 & 391 \\
CK14 & 197386 & 9179845 & 413 \\
CK16 & 195399 & 9177836 & 409 \\
CK17 & 195464 & 9177961 & 395 \\
CK18 & 195636 & 9177978 & 384 \\
CK19 & 195799 & 9178068 & 374 \\
CK20 & 196171 & 9177862 & 387 \\
CK21 & 195122 & 9177582 & 389 \\
CK22 & 195676 & 9177618 & 403 \\
CK23 & 196096 & 9177247 & 445 \\
\hline
\end{tabular}

In general, the results of outcrop observation are in accordance with the Geological Map, where the lithology consists of sedimentary, pyroclastic, and igneous rocks (Figure 2). In addition, the dip direction of rock layers is also matches with the dip direction as seen from the geological cross section on the Geological Map of the Tasikmalaya Quadrangle, West Java by Budhitrisna (1986). The strike and dip of rock layer can be observed only in four outcrops, CK6; CK7; CK10; and CK19. The dip of rock layers at CK6; CK7; and CK19 is oriented towards NE-E (Figure 2). Meanwhile, the dip of rock layers is oriented towards NW at CK10. These results are in accordance with the cross-section on the Geological Map of Tasikmalaya where the dip of the rock layers is oriented relatively to the north (Budhitrisna, 1986).

Furthermore, to predict the rock layer beneath the study area, a simple geological cross-section which is only based on data in the southern part of the study area, especially CK17, CK18, and CK19 was made (Figure 3). The reason why the rock layers in the outcrops of northern area were not used to make the cross section is related to their dip direction, which is oriented relatively to the north (Figure 2). Here, it can be assumed that those rock layers can't be found beneath the Cikakaban Village, because they are younger than the rock layers in the southern area.

We made the cross section with the assumption of a uniform dip of all of rock layers, because only the strike and dip from the layers in the CK19 can be obtained. Figure 3 shows the two zone beneath the study area, the green zone and blue zone. The green zone is composed of fine-grains rock layers, which is estimated from the rock characteristics in the CK17, CK18, and CK19. Meanwhile, the blue 
zone is also composed of fine-grains rock layers, however the blue zone was estimated from the soil characteristics around the study area due to the absence of outcrop there. The soil characteristics there are similar with the soil near CK17, CK18, and CK19. In this case, it can be predicted that the rock characteristics around the study area is also similar with the rocks in the CK17, CK18, and CK19, especially in grain size. Based on the cross section, it can be estimated that the fine-grains rock layers are still found from the depth of $120 \mathrm{~m}$ (beneath the lowest part of the study area) to $165 \mathrm{~m}$ (beneath the highest part of the study area) (Figure 3).

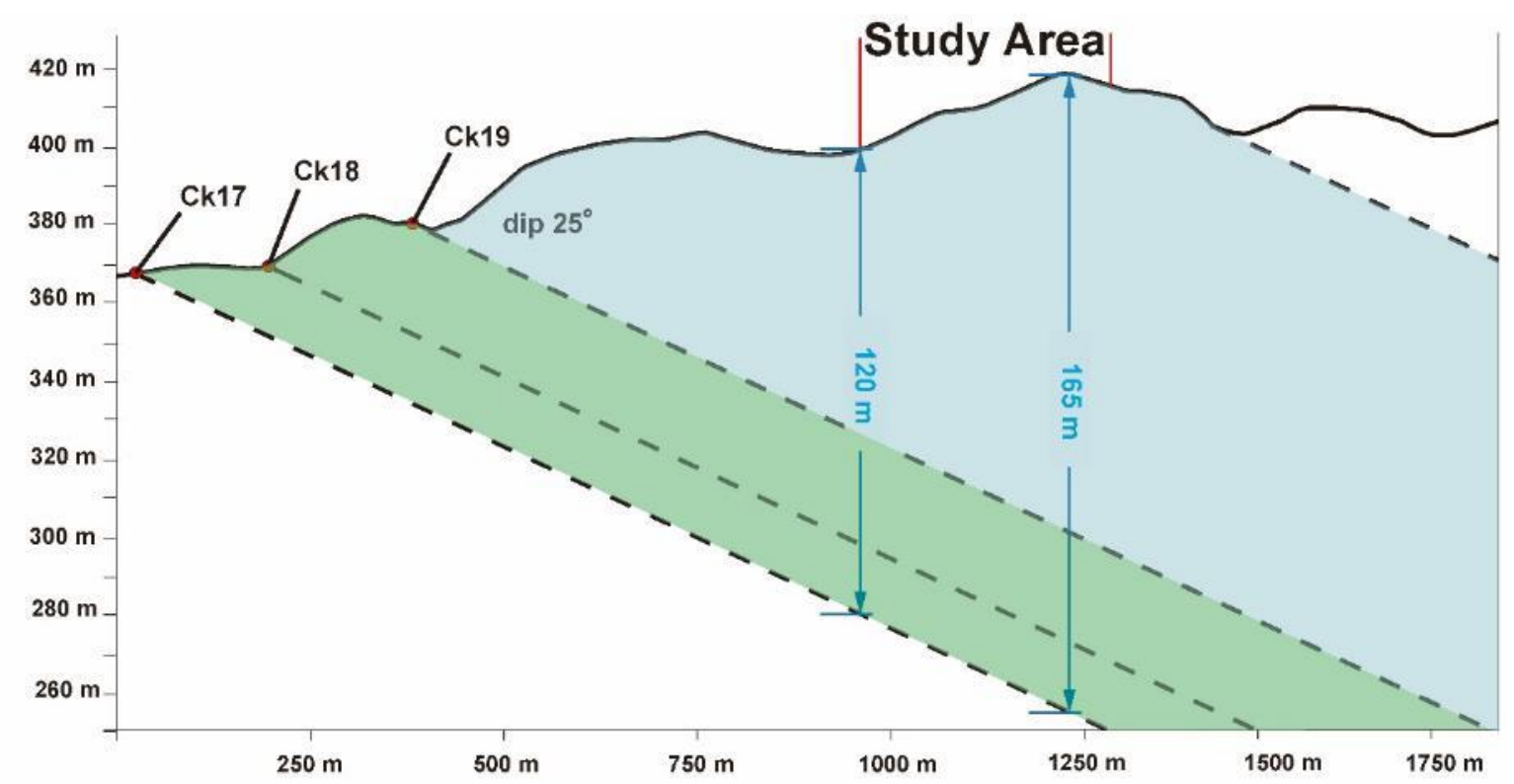

Fig 3. Simple geological cross section in the southern part of study area. Dash lines show the dip of rock layer.

The explanations above show that the rock layers beneath study area don't have good potential as aquifers due to their predominantly fine grain size. However, the presence of geological structures in the study area allows the existence of a secondary porosity (Morris et al, 2003; Lachassagne et al., 2011; Tadesse, 2017; Adebayo and Abraham, 2008; and Bauer et al., 2016). The evidences of the geological structure were found in several outcrops, including CK4; CK5; CK6; CK18; CK19; and CK20, in the form of joints, shear fractures, and minor faults (Supplementary Material Figures S3, S4, S6, S19, S20, and S22). Based on their location, rock layers that show geological structure evidence are thought to be found beneath the study area. Even though the rock layers are dominantly finegrained, it is still possible to find secondary porosity, such as fracture, which could play as a migration route and groundwater storage medium. Moreover, the research area is cut by a fault (estimated) which could also play as a migration route and groundwater storage medium (Figure 2). However, the existence of this fault should be further analyzed on the next research.

Several studies have confirmed that the presence of geological structures, which are manifested in the form of fractures, joints, faults, and shear zones, can be a medium for groundwater transport and storage. Tadesse (2017) showed that the bedrock in the Tsalit-Ira River Basin, Tigray, Northern Ethiopia, in the form of volcanic and metamorphic rocks, can function as an aquifer due to the presence of the weak zone, as mentioned above. Meanwhile, Bauer et al. (2016) showed that the presence of faults in massive carbonate rocks and low porosity in the Hochschwab karst massif (Austria), can function as a fluid medium that can be infiltrated and transported.

\subsection{Hydrogeological Setting of Research Area}

Based on the Hydrogeological Map of Tasikmalaya (Soetrisno, 1990) (Figure 4), the study area has low-productivity and low-continuity aquifers. Shallow groundwater can be found in limited quantities in valleys or in weathering zones. Thus, it is not surprising that Riyadi and Wibowo (2007) found Cikakaban as an area with very low groundwater potential.

Regarding water resources, Figure 4 shows the intermittent tributaries around the study area, with the closest distance between $0.5-1 \mathrm{~km}$. The intermittent river is refers to all temporary, ephemeral, 
seasonal, and episodic streams and rivers (Datry et. al., 2014 and costigan et. al., 2016). Based on discussions with residents, these rivers are usually dry during the dry season. Meanwhile, the main river (Ciwulan River) is about $7 \mathrm{~km}$ west of the study area, with the flow direction from north to south.

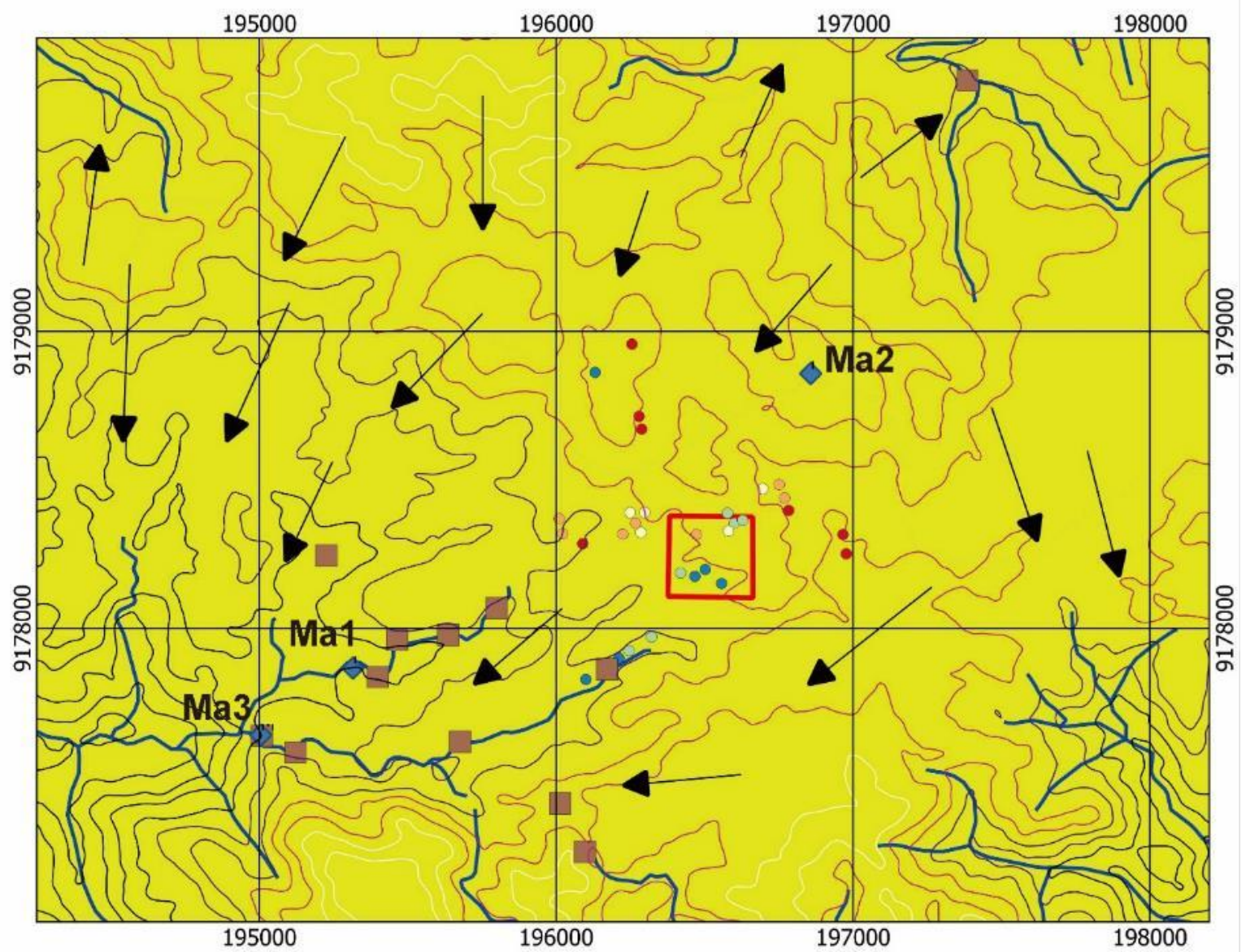

\section{Legend}
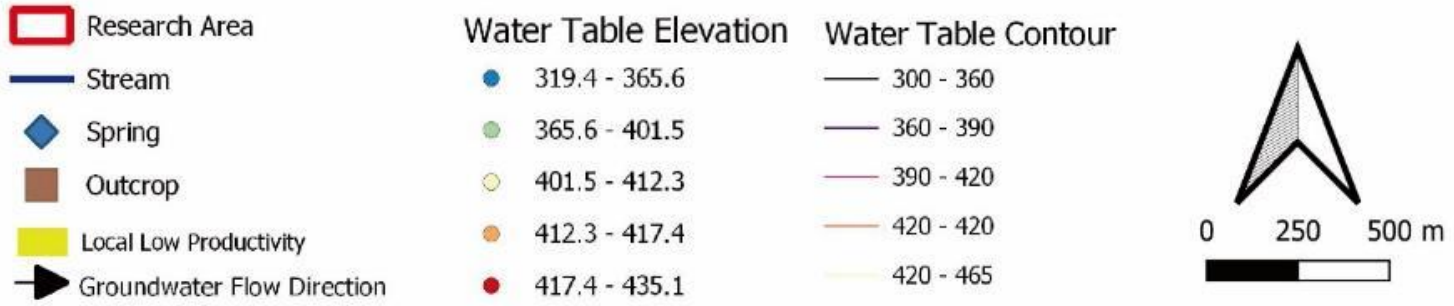

Fig 4. Hydrogeological map showing the location of water resources around the research area.

Apart from rivers, other water resources around study area are groundwater which were observed through wells and springs (Figure 4). The groundwater, observed through wells, is estimated to be contained in a free aquifer system, where topography is the main control for the direction flow. This condition was characterized by its shallow groundwater level (the depth from the surface were about 0.3-3 $\mathrm{m}$ in the valley and 3-6 $\mathrm{m}$ on the slopes). In addition, indications of the free aquifer system could be seen from the dry wells during the dry season. It showed that the groundwater condition in the wells is strongly influenced by the conditions on the surface. This condition was also indicated by lithological conditions near the surface. The lithology in the study area is consisted of fine-grained tuff that forms an impermeable layer. This layer is only able to store rainwater infiltration for a limited time. Thus, the wells are dry during the dry season due to the reduced rainwater infiltration. In general, the flow direction of groundwater in the study area follows the topography, where the general flow was relatively directed to the south (Figure 4). The springs found in the study area can be classified into contact springs between tuff and lava layers (MA1 and MA3) and springs that are influenced by 
geological structures (MA2) (Figure 5). The nearest spring from the study area was MA2, with a distance of about $0.5 \mathrm{~km}$. The MA1 and MA3 were located more than $1 \mathrm{~km}$ from the research area.

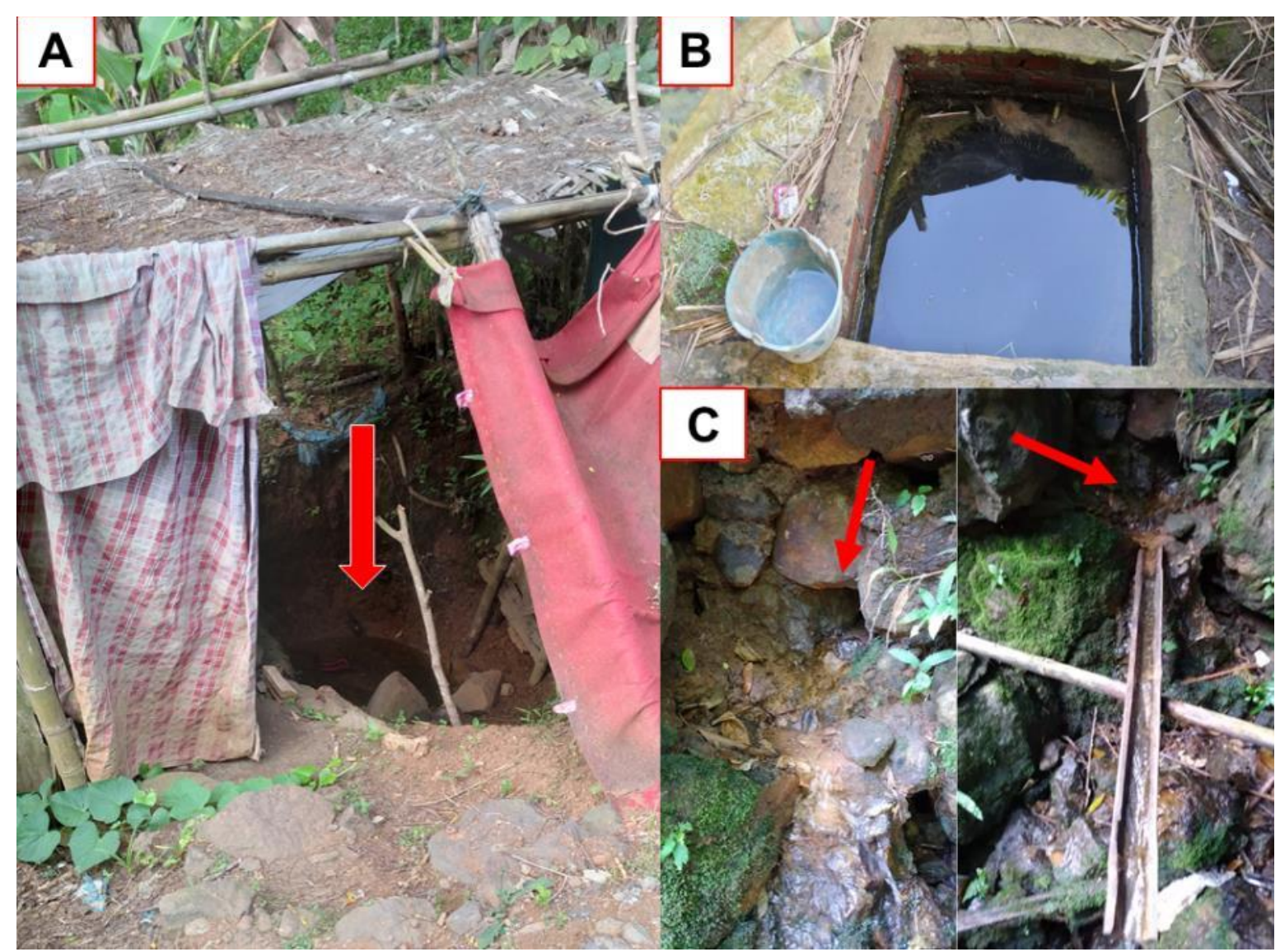

Fig 5. Springs condition of (A) MA1, (B) MA2, and (C) MA3.

\section{Conclusions}

In general, the research area was composed of lithology with fine-grain size and moderate to poor permeability. The dominant rock layers beneath the research area are consist of claystone and tuff, with the dip direction relatively to the North-East. The two lithologies that have no potential as aquifers are estimated to be found until a depth of 140-165 m beneath the study area. However, the presence of geological structures causes the fine-grain size lithology to potentially become aquifers. The presence of these geological structures was indicated by the presence of joints, shear fractures, and minor faults in several outcrops found southward of the study area. The rock layers in these outcrops are estimated to extend into the study area.

Here, potential water resources found around the research area are groundwater, springs, and rivers. Groundwater, observed through wells, can be classified as a free aquifer system, with a groundwater level depth of 0.3-6 m. This groundwater is only temporary because during the dry season the wells dry up. The groundwater flows relatively to the south of the study area. Meanwhile, the nearest spring from the study area is $0.5 \mathrm{~km}$ away, where its presence is thought to be controlled by geological structures. Another water resource is intermittent rivers, within $0.5-1 \mathrm{~km}$ from the research area.

\section{Author Contributions}

A.P. and A.H. conceived and designed the surveys; A.P. collected the samples; A.P. and A.H. performed the experiments; and A.P., A.H., R.D.W.A., and Y.A.P. analyzed the data and wrote the paper. 


\section{Acknowledgments}

This study was financially supported by the Social Activities Grant from the Dompet Dhuafa Jawa Barat to A.P. We thank the Dompet Dhuafa Volunteers, GeoSoftware Community, Hayu Bareng Community, Gerakan Madani Tasikmalaya Community, Aquifera Nusantara, and LPDP Water Professional for their supports and assistance in the field. We thank anonymous reviewers for their constructive comments and criticisms.

\section{References}

Adebayo, O.S., Abraham, A.A., 2018. Aquifer, Classification and Characterization, in: Javaid, M.S., Khan, S.A. (Eds.), Aquifers - Matrix and Fluids. InTech. https://doi.org/10.5772/intechopen.72692

Agosta, F., Alessandroni, M., Antonellini, M., Tondi, E., Giorgioni, M., 2010. From fractures to flow: A field-based quantitative analysis of an outcropping carbonate reservoir. Tectonophysics 490, 197-213. https://doi.org/10.1016/j.tecto.2010.05.005

Agosta, F., Ruano, P., Rustichelli, A., Tondi, E., Galindo-Zaldívar, J., Sanz de Galdeano, C., 2012. Inner structure and deformation mechanisms of normal faults in conglomerates and carbonate grainstones (Granada Basin, Betic Cordillera, Spain): Inferences on fault permeability. Journal of Structural Geology 45, 4-20. https://doi.org/10.1016/j.jsg.2012.04.003

Bauer, H., Schröckenfuchs, T.C., Decker, K., 2016. Hydrogeological properties of fault zones in a karstified carbonate aquifer (Northern Calcareous Alps, Austria). Hydrogeol J 24, 1147-1170. https://doi.org/10.1007/s10040-016-1388-9

Budhitrisna, T., 1986. Peta Geologi Lembar Tasikmalaya, Jawa Barat.

Chowdary, V.M., Ramakrishnan, D., Srivastava, Y.K., Chandran, V., Jeyaram, A., 2009. Integrated Water Resource Development Plan for Sustainable Management of Mayurakshi Watershed, India using Remote Sensing and GIS. Water Resources Management 23, 1581-1602. https://doi.org/10.1007/s11269-008-9342-9

Costigan, K.H., Jaeger, K.L., Goss, C.W., Fritz, K.M., Goebel, P.C., 2016. Understanding controls on flow permanence in intermittent rivers to aid ecological research: integrating meteorology, geology and land cover. Ecohydrology 9, 1141-1153. https://doi.org/10.1002/eco.1712

Datry, T., Larned, S.T., Tockner, K., 2014. Intermittent Rivers: A Challenge for Freshwater Ecology. BioScience 64, 229-235. https://doi.org/10.1093/biosci/bit027

Faulkner, D.R., Jackson, C.A.L., Lunn, R.J., Schlische, R.W., Shipton, Z.K., Wibberley, C.A.J., Withjack, M.O., 2010. A review of recent developments concerning the structure, mechanics and fluid flow properties of fault zones. Journal of Structural Geology 32, 1557-1575. https://doi.org/10.1016/j.jsg.2010.06.009

Iskandar, A.H., 2021. SDGs Desa. SDGs Desa. URL https://sdgsdesa.kemendesa.go.id/sdgs-desa-2/ Kemendes, 2020. SDGs Desa Nomor 6: Desa Layak Air Bersih dan Sanitasi. SDGs Desa Nomor 6: Desa Layak Air Bersih dan Sanitasi. URL https://sdgsdesa.kemendesa.go.id/sdgs-desa-nomor6-desa-layak-air-bersih-dan-sanitasi/

Lachassagne, P., Wyns, R., Dewandel, B., 2011. The fracture permeability of Hard Rock Aquifers is due neither to tectonics, nor to unloading, but to weathering processes: Weathering and permeability of Hard Rock Aquifers. Terra Nova 23, 145-161. https://doi.org/10.1111/j.13653121.2011.00998.x

Lange, G., Yaramanci, U., Meyer, R., 2007. Surface Nuclear Magnetic Resonance, in: Environmental Geology. Springer Berlin Heidelberg, Berlin, Heidelberg, pp. 403-430. https://doi.org/10.1007/978-3-540-74671-3_12

Morris, B.L., Lawrence, A.R.L., Chilton, P.J.C., Adams, B., Calow R.C., Klinck, B.A. 2003. Groundwater and its Susceptibility to Degradation: A Global Assessment of the Problem and Options for Management. Early Warning and Assessment Report Series, RS. 03-3. United Nations EnvironmentProgramme, Nairobi, Kenya

Nugraha, I., 2016. Warga Satu Kampung di Kota Tasikmalaya Tak Punya WC Sendiri. Warga Satu Kampung di Kota Tasikmalaya Tak Punya WC Sendiri. URL https://regional.kompas.com/read/2016/10/19/11124501/warga.satu.kampung.di.kota.tasikm alaya.tak.punya.wc.sendiri 
Riyadi, A., Wibowo, K., 2007. Karakteristik Air Tanah di Kecamatan Tamansari Kota Tasikmalaya. J. Tek. Ling 8, 197-206. https://doi.org/10.29122/jtl.v8i3.425

Rudiyanto, A., 2020. Ringkasan Eksekutif Pelaksanaan Pencapaian Tujuan Pembangunan Berkelanjutan/Sustainable Development Goals (TPB/SDGs) Tahun 2019. Kedeputian Bidang Kemaritiman dan Sumber Daya Alam, Kementerian Perencanaan Pembangunan Nasional/Badan Perencanaan Pembangunan Nasional.

Tadesse, N., 2017. Lithological and structural controls on the development of aquifer in basement rock dominated Tsalit- Ira River Basin, Tigray, Northern Ethiopia. mejs 9, 106. https://doi.org/10.4314/mejs.v9i1.8 